KS. HENRYK STAWNIAK SDB

Wydział Prawa Kanonicznego

Uniwersytetu Kardynała Stefana Wyszyńskiego w Warszawie

GRAŻYNA JARZĄBEK-BIELECKA

Uniwersytet Medyczny w Poznaniu

ANNA BIELECKA-GĄSZCZ

Sąd Rejonowy w Łodzi

\title{
PRZEMOC SEKSUALNA WOBEC MAŁOLETNICH I ICH OCHRONA PRAWNO-ETYCZNA I KANONICZNA
}

Treść: Wstęp. - 1. Aspekt prawno-etyczny zagadnienia. - 1.1. Typy przestępstw seksualnych. - 1.2. Ochrona małoletnich. - 1.3. Sankcje karne. - 1.4. Pojęcia - dziecko i nieletni. - 1.5. Podsumowanie. - 2. Aspekt kanoniczny przemocy seksualnej wobec małoletnich. - 2.1. Rodzaje przestępstw wobec małoletnich i sankcje karne. - 2.1.1. Molestowanie seksualne - pojęcie i strona przedmiotowa przestępstwa. - 2.1.1.1. Strona podmiotowa przestępstwa. - 2.1.1.2. Sankcje karne. - 2.1.2. Przestępstwo pornografii dziecięcej. - 2.1.2.1. Strona podmiotowa przestępstwa. - 2.1.2.2. Strona przedmiotowa przestępstwa. - 2.1.2.3. Dolus specificus i sankcje karne. - 2.2. Przedawnienie czynów kryminalnych wobec małoletnich. - 2.3. Troska Kościoła o ochronę małoletnich. - Zakończenie.

\section{Wstęp}

W dobru wspólnym państwa i Kościoła mieści się troska o ochronę dzieci i młodzieży. Zadaniem tych społeczności jest najpierw uznanie i respektowanie praw małoletnich oraz troska o to, by stworzyć 
im bezpieczne środowiska rozwoju, wolne od wykorzystywania, przemocy i manipulacji. Społeczność państwowa i kościelna są zobowiązane do służby na rzecz rozwoju fizycznego, duchowego i emocjonalnego dzieci i młodzieży oraz wykluczania sytuacji, by w jakikolwiek sposób naruszano fizyczną lub psychiczną integralność małoletnich. Wszelkie nadużycia w tym względzie są przez obie społeczności powszechnie potępiane i wzbudzają słuszne oburzenie. W obu społecznościach czyny związane z przemocą wśród dzieci i młodzieży są uważane za ciężkie przestępstwa. Niepokojące zjawiska związane z molestowaniem seksualnym czy też pornografią dziecięcą spowodowały powstanie przepisów surowo penalizujących te przestępstwa. Wydaje się z punktu widzenia naukowego, że może być interesujące przedstawienie przemocy seksualnej wobec małoletnich w systemie prawnokarnym i etycznym oraz kanonicznym. Ta komparatystyka pokaże rozumienie przestępstw w obu systemach, ofiary przestępstw i ich sprawców, sankcje karne oraz rzeczywistą troskę państwa i Kościoła o ochronę małoletnich.

\section{Aspekt prawno-etyczny zagadnienia}

Od początku cywilizacji seksualność była objęta regulacją obyczajową i prawną. Jednak sformułowania zasad normujących seksualność człowieka różnią się w zależności od epoki, od poziomu kulturalnego, od warunków geograficznych i klimatycznych, a także w zależności od warunków życia danego społeczeństwa. Już najstarsze cywilizacje państwowe posiadały pewne regulacje prawne dotyczące seksualności'. Polskie prawo karne nie definiuje wprost pojęcia przestępstwa, które etymologicznie wywodzi się od określenia z prawa rzymskiego

\footnotetext{
${ }^{1}$ Por. G. JARzĄBEK-BieleckA, Health promotion, ethics and legal aspects in adolescents gynecology and sexology, Archives of Perinatal Medicine 22(1), 2016, s. 39-42; G. Jarząbek-Bielecka, M. Jarząbek, M. Kownacka, A. Bielecka-Gąszcz, Z. Jarząbek, M. Borowczyk, A. Chmielarz-Czarnocińska, K. Stachewicz, E. SoWIŃSKA-PrzePiera, W. KęDZIA, Legal, psychologic, medical and ethic aspects about responsibility in sexuality and sexual relations - in the light of Józef Tischner's thoughts on sex, w: VIII Krakowska Konferencja Psychologii Sądowej. 8th Cracow Conference of Psychology and Law, Kraków 28.11.2015-29.11.2015, s. 78-79.
} 
(łac. crimen). Definicję taką można jednak skonstruować na podstawie przepisów części ogólnej Kodeksu karnego z 1997 roku (ustawa z dnia 6 czerwca 1997 roku - Kodeks Karny, tj.: Dz.U. 2016, poz. 1137, która weszła w życie 1 września 1998 roku), który jest najważniejszym, po konstytucji, źródłem prawa karnego. Na gruncie polskiego prawa karnego przestępstwem jest czyn zabroniony pod groźbą kary jako zbrodnia albo występek, przez ustawę obowiązującą w czasie jego popełnienia, bezprawny, zawiniony i społecznie szkodliwy w stopniu wyższym niż znikomy.

Ze względu na przedmiot ochrony (rodzaj dóbr chronionych prawem), wśród przestępstw można wyróżnić przestępstwa przeciwko wolności seksualnej i obyczajności. Pewne zachowania seksualne są zatem regulowane przez prawo - przepisy prawa zabraniają pewnych czynów seksualnych pod groźbą sankcji karnych. Według Leszka Lernella (1984) przestępstwa seksualne to „takie typy zachowań ludzkich (wraz z ich skutkami), powiązane z życiem seksualnym człowieka, jakie są zakazane przez ustawodawstwo karne". Przestępstwa seksualne, jakiekolwiek zastosujemy w ich obrębie zróżnicowanie, łączy ten sam przedmiot ochrony, jakim jest wolność seksualna i obyczajność. Jednakże wszelkie pozostałe czynniki takie jak źródła społeczne przestępstwa, motywy działania sprawcy, zakres ochrony są od siebie odmienne. Ustawodawca chroni jedną z najbardziej istotnych sfer każdego człowieka, jaką jest jego sfera seksualna. Wszelkie jej naruszenia wbrew woli osoby, której dotyczą, są karane. Niestety ofiarami przestępstw seksualnych bywają nierzadko dzieci - to szczególnego rodzaju zło - w ginekologii dziecięcej i dziewczęcej jest to doniosły problem ściśle związany także z psychologią-seksuologiąㄹ.

\footnotetext{
${ }^{2}$ Por. Z. Toвor, O wykładni, Studia Prawnicze, 2009, s. 3; M. Filar, Prawo i seks, Problemy rodziny, nr 1-2, 1997, s. 6; www.kidprotect.pl Świat Przyjazny Dzieciom; www.wikipedia.org/wiki/Obcowanie płciowe. Obcowanie płciowe - spółkowanie lub jego surogat, np. stosunek oralny lub analny (data dostępu 8.06.2016); M. FILAR, Komentarz do Kodeksu karnego, wydanie 2, (red. Oktawii Górniok), Wydawnictwo Prawnicze LexisNexis, Warszawa 2006, ss. 549, 565, 573, 621, 641, 729; Z. LEW-STARowicz, Seksuologia sq̨dowa, Wydawnictwo Prawnicze, Warszawa 2000, s. 229-231.
} 
W Kodeksie karnym z 1997 roku przestępstwa przeciwko wolności seksualnej i obyczajności ujęte zostały w rozdziale XXV, przepisach od art. 197 do 205 Kodeksu karnego (dalej k.k.). W ukształtowaniu obecnie obowiązującego kodeksu karnego ważną rolę odegrał Kodeks karny z 1932 roku (Rozporządzenie Prezydenta Rzeczypospolitej z dnia 11 lipca 1932 roku - Kodeks karny, Dz.U. 1932, Nr 60, poz. 571, który wszedł w życie 1 września 1932 roku) oparty na filozofii materialistycznej. W rozdziale XXXII Kodeksu karnego z 1932 roku, zatytułowanym „Nierząd”, wszystkie zawarte w nim przestępstwa seksualne uważane były za „czyny nierządne”, wymierzone przeciwko określonemu „rządowi”, porządkowi w sferze seksualnej. Obowiązujący potem Kodeks karny z 1969 roku (ustawa z dnia 19 kwietnia 1969 roku - Kodeks karny, Dz.U. 1969, Nr 13, poz. 94, który wszedł w życie 1 stycznia 1970 roku) odstąpił częściowo od tej inspiracji, opierając się np. na gruncie filozofii wolnościowej. W kodeksie tym przestępstwa seksualne znalazły się w dwóch następujących po sobie rozdziałach, to jest w rozdziale XXII zatytułowanym „Przestępstwa przeciwko wolności” i w rozdziale XXIII zatytułowanym „Przestępstwa przeciwko obyczajności".

Rozdział XXV Kodeksu Karnego z 1997 roku jest wyrazem kompromisu między dwiema odmiennymi koncepcjami kryminalizacji zachowań związanych z przejawami życia seksualnego człowieka. Według teorii tzw. moralistycznej przedmiotem ochrony rodzajowej jest tzw. obyczajność seksualna, rozumiana jako zespół reguł społeczno-kulturowych rządzących tymi zachowaniami w aktualnej formacji społecznej. Obyczajność ta jest dobrem ogólnym i abstrakcyjnym, wymierzone przeciwko niej przestępstwa zaś mają charakter tzw. przestępstw bez ofiar, gdzie przedmiotem zamachu nie jest określona osoba, lecz ogólnie i abstrakcyjnie rozumiany standard zasad obyczajowych. Zgodnie z drugą koncepcją, tzw. wolnościową, przedmiotem ochrony rodzajowej jest wolność konkretnej osoby od wszelkich form przymusu w sferze życia seksualnego. Nikt nie może być zmuszany ani też skłaniany za pomocą sposobów wykluczających możliwość podjęcia przezeń decyzji woli o walorze prawnym do podejmowania lub uczestniczenia w aktach czy wydarzeniach o charakterze 
seksualnym. Przestępstwa seksualne tracą charakter przestępstw bez ofiar, gdyż pokrzywdzonym jest tu zawsze konkretna osoba ${ }^{3}$.

\subsection{Typy przestępstw seksualnych}

Prawo karne przewiduje następujące typy przestępstw seksualnych:

1) obcowanie płciowe lub inne czynności seksualne pozbawione cech faktycznej dobrowolności ze strony jednego z partnerów (zgwałcenie - doprowadzenie innej osoby przemocą, groźbą bezprawną lub podstępem do obcowania płciowego; wymuszenie czynności seksualnej - doprowadzenie innej osoby przemocą, groźbą bezprawną lub podstępem do poddania się innej czynności seksualnej albo do wykonania takiej czynności; wykorzystanie bezradności innej osoby, wykorzystanie wynikającego z upośledzenia umysłowego lub choroby psychicznej braku zdolności tej osoby do rozpoznania znaczenia czynu lub pokierowania swoim postępowaniem; nadużycie stosunku zależności lub wykorzystanie krytycznego położenia);

- obcowanie płciowe obejmuje swym zakresem przede wszystkim klasyczny akt spółkowania heteroseksualnego, jak również wszelkie jego surogaty traktowane przez sprawcę jako ekwiwalentne i równoważne spółkowaniu, a polegające na bezpośrednim kontakcie płciowych części ciała jednego z uczestników aktu z częściami ciała drugiego uczestnika, które wprawdzie obiektywnie płciowymi nie są, lecz które sprawca traktuje jako ekwiwalentne częściom płciowym, wyładowując za ich pośrednictwem swoje libido, np. stosunek oralny i analny hetero- i homoseksualny ${ }^{4}$;

- inne czynności seksualne to wszelkie zachowania o seksualnym wyrazie i intencji, niebędące obcowaniem płciowym $\mathrm{w}$ rozumieniu art. $197 \$ 1$ k.k., a polegające na cielesnym kontakcie uczestników takiego czynu lub przynajmniej cielesnym i mającym charakter seksualny zaangażowaniu ofiary,

\footnotetext{
${ }^{3}$ Por. M. Filar, Komentarz do Kodeksu karnego, dz. cyt., ss. 549, 565, 624.

${ }^{4}$ Por. Tamże, s. 673.
} 
np. dotykanie narządów płciowych ofiary, zmuszanie jej do onanizowania innej osoby, do obnażania czy onanizowania się, wykonywania określonych cielesnych manipulacji seksualnych (uchwała SN z dnia 19 maja 1999 roku, I KZP 17/99, OSP 1999, nr 12, poz. 224) ${ }^{5}$;

2) pedofilia (obcowanie płciowe $z$ małoletnim poniżej lat 15 lub dopuszczenie się wobec takiej osoby innej czynności seksualnej lub doprowadzenie jej do poddania się takim czynnościom albo do ich wykonania);

3) ekshibicjonizm (zachowanie seksualne przejawiane publicznie lub w obecności dzieci);

4) kazirodztwo (dopuszczenie się obcowania płciowego w stosunku do wstępnego, zstępnego, przysposobionego, przysposabiającego, brata lub siostry);

5) prezentowanie treści pornograficznych (szczegółowo uregulowane w art. $202 \mathrm{k} . \mathrm{k}$. - m.in. publiczne prezentowanie treści pornograficznych narzucające ich odbiór osobie, która sobie tego nie życzy; w celu rozpowszechniania produkowanie, utrwalanie lub sprowadzanie, przechowywanie lub posiadanie albo rozpowszechnianie lub prezentowanie treści pornograficznych z udziałem małoletniego albo treści pornograficznych związanych $z$ prezentowaniem przemocy lub posługiwaniem się zwierzęciem; utrwalanie treści pornograficznych z udziałem małoletniego; przechowywanie, posiadanie lub uzyskiwanie dostępu do treści pornograficznych z udziałem małoletniego);

6) przestępstwa stymulujące $\mathrm{w}$ jakiś sposób uprawianie prostytucji przez inną osobę (stręczycielstwo - nakłanianie innej osoby do uprawiania prostytucji w celu osiągnięcia korzyści majątkowej; kuplerstwo - ułatwianie innej osobie uprawiania prostytucji w celu osiągnięcia korzyści majątkowej; sutenerstwo - czerpanie korzyści majątkowych $\mathrm{z}$ uprawiania prostytucji przez inną osobę).

\footnotetext{
${ }^{5}$ Por. Tamże, ss. 617, 683, 729.
} 
Warto zwrócić uwagę na sposób, w jaki doktryna prawa karnego określa przedmiot ochrony objęty regulacjami artykułów dotyczących przestępstw seksualnych i na tle seksualnym. Podstawową wartością, która znajduje się pod ochroną przepisów prawa karnego odnoszącego się do sfery życia seksualnego jest indywidualna wolność jednostki, i to wolność definiowana w sposób pozytywny, jak i negatywny a więc wolność DO samodzielnego i swobodnego podejmowania decyzji związanych z życiem płciowym (o tyle, o ile nie wyrządza to krzywdy innej jednostce i nie przynosi obiektywnego uszczerbku realnym interesom społecznym ${ }^{6}$, ale też wolność OD wszelkiego fizycznego i psychicznego przymusu w tej intymnej sferze życia.

\subsection{Ochrona małoletnich}

W sposób szczególny prawo karne chroni sferę seksualności osób małoletnich (zatem osób, które nie ukończyły lat 18). W projekcie Kodeksu karnego z 1969 roku ustawodawca wskazywał na szczególną potrzebę ochrony prawidłowego rozwoju psychicznego i fizycznego małoletnich, na potrzebę zapobieżenia ich deprawacji i demoralizacji a także na konieczność zapewnienia bezpiecznych warunków do normalnego rozwoju psychofizycznego dziecka. Warto przy tym zauważyć, że ochrona wolności seksualnej małoletniego nie polega bynajmniej, tak jak w przypadku ochrony wolności osoby dorosłej, na pełnym poszanowaniu decyzji woli małoletniego, ale na ochronie wolności seksualnej wtedy, gdy dana osoba małoletnia nie jest w stanie podejmować i wyrażać swoich decyzji (np. niemowlę) albo wtedy, gdy z powodu niedojrzałości jej decyzje nie mogą być traktowane jako wystarczająco przemyślane. Niekiedy może się więc zdarzyć, że ze względu na wysoki indywidualny stopień socjalizacji i rozwoju świadomości seksualnej u małoletniego, prawo będzie działało niejako wbrew woli osoby chronionej.

W różnych krajach i środowiskach ten sam czyn dotyczący sfery seksualnej życia człowieka będzie podlegał innym regulacjom (lub

\footnotetext{
${ }^{6}$ Por. N. Goodman, Dewiacja i kontrola społeczna, Wstęp do socjologii, Wydawnictwo Zysk i Ska, Poznań 1992, s. 109.
} 
nie będzie podlegał żadnym) i może być różnie interpretowany. Przykładem może być obcowanie płciowe $\mathrm{z}$ osobą małoletnią lub dopuszczenie się innej czynności seksualnej lub doprowadzanie jej do poddania się takim czynnościom albo do ich wykonania. W Polsce, ustawodawca chcąc chronić osoby, nie będące dojrzałe psychicznie i fizycznie przed przedwczesnym rozpoczęciem współżycia, ustalił granicę wiekową, poniżej której, zachowania seksualne wobec osób zaliczonej do tej grupy są karane. W Polsce granica wieku została ustalona na poziomie 15 lat. Seksualne wykorzystanie małoletniego poniżej lat 15, w sposób określony w przepisie art. $200 \$ 1$ k.k., jest zagrożone karą pozbawienia wolności od 2 do 12 lat $^{7}$.

$\mathrm{Na}$ świecie wiek uprawniający do podjęcia współżycia seksualnego wynosi średnio 15 - 18 lat. W niektórych regionach ten wiek wynosi jednak 9 - 21 lat. Na osąd w kwestiach związanych z czynami seksualnymi może wpływać wiele czynników, dlatego ważne jest, aby przy dokonywaniu ocen zwracać uwagę na uwarunkowania kulturowe i prawne funkcjonujące $\mathrm{w}$ danym kraju.

\subsection{Sankcje karne}

Ustawodawca chroni zatem sferę seksualną, jako najbardziej intymną, a jednocześnie jedną z najbardziej istotnych sfer każdego człowieka. Wszelkie naruszenia tej sfery wbrew woli osoby, której dotyczą są karalne. Tym samym doprowadzenie innej osoby do obcowania płciowego przemocą, groźbą bezprawną lub podstępem stanowi przestępstwo zgwałcenia w jego podstawowej postaci, które obecnie zagrożone jest karą pozbawienia wolności od lat 2 do 12 (art. $197 \$ 1$ k.k.). Jeżeli sprawca, działając takimi samymi metodami, doprowadza inną osobę do poddania się innej czynności seksualnej albo wykonania takiej czynności, podlega karze pozbawienia wolności od 6 miesięcy do lat 8 (art. $197 \$ 2$ k.k.). Z kolei, jeżeli sprawca dopuszcza się zgwałcenia: 1) wspólnie $z$ inną osobą, 2) wobec małoletniego, 3) wobec wstępnego, zstępnego, przysposobionego, przysposabiającego, brata

\footnotetext{
${ }^{7}$ Por. J.H. Turner, Socjologia - koncepcje i ich zastosowanie, Wydawnictwo Zysk i Ska, Poznań 1994, s. 203.
} 
lub siostry, podlega karze pozbawienia wolności na czas nie krótszy od lat 3 (art. $197 \$ 3$ k.k.). Jeżeli sprawca czynu określonego w art. $197 \$ 1-3$ działa ze szczególnym okrucieństwem (używa więcej przemocy niż potrzeba do osiągnięcia przestępnego celu), podlega karze pozbawienia wolności na czas nie krótszy od lat 5 (art. $197 \S 4$ k.k.). W orzecznictwie sądów i doktrynie prawa karnego przyjmuje się przy tym powszechnie, że zgwałcenie dziecka jest zawsze działaniem ze szczególnym okrucieństwem, gdyż wywołuje niepowetowane szkody w psychice dziecka.

Przez użyte w kodeksie określenie „inna czynność seksualna” należy rozumieć (uchwała SN z dnia 19 maja 1999 roku, I KZP 17/99, OSNKW 1999/7-8/37) zachowanie, nie mieszczące się w pojęciu „obcowania płciowego", które związane jest z szeroko rozumianym życiem płciowym człowieka, polegające na kontakcie cielesnym sprawcy z pokrzywdzonym lub przynajmniej na cielesnym i mającym charakter seksualny zaangażowaniu ofiary. „Inna czynność seksualna” to „akt spółkowania lub jego surogat”, podczas którego „nie musi dojść do immissio penis", musi natomiast dojść (by mogło dane zachowanie zostać nazwane inną czynnością seksualną) do cielesnego kontaktu między osobami, w szczególności okolicznością wskazującą na fakt dokonania innej czynności seksualnej będzie „dotykanie narządów płciowych lub innych z którymi kontakt prowadzi do zaspokojenia sprawcy czynu".

Teorie prawa karnego podają następujące warunki zaklasyfikowania danego czynu jako przestępstwa seksualnego: występował zamiar o charakterze seksualnym, charakter seksualny ma zarówno czyn jak i jego rezultat oraz gdy wystąpił atak na ofiarę ${ }^{8}$. Przestępstwem jest zatem czynność seksualna w sytuacji, gdy brak jest zgody jednego z uczestników (np. zgwałcenie). Przedmiotem ochrony prawa karnego jest dobro indywidualne - prawo do wolności seksualnej. Istnieją jednak czynności uznawane przez kodeks karny za przestępstwa mimo, iż nie zostały naruszone wartości indywidualne, ponieważ czynności

\footnotetext{
${ }^{8}$ Por. B. HoŁyst, Kryminalistyka, Wydawnictwo Prawnicze PWN, Warszawa 2003, s. 73.
} 
seksualne przebiegają za zgodą osób w niej uczestniczących - czyli nie ma ofiar, ale wykraczają przeciw dobru ogólnemu czyli obyczajowości seksualnej; przykładem takiego przestępstwa jest prostytucja, gdyż stanowi naruszenie zasad obowiązujących w danym społeczeństwie9

Z perspektywy medycznej do przestępstwa seksualnego dochodzi, gdy zachowanie przestępcze motywowane było chęcią zaspokojenia popędu płciowego. Okazuje się jednak, że czasami u podłoża zachowań seksualnych mogą leżeć pozaseksualne motywy, np. zemsta czy chęć ukarania.

Mając na uwadze wszystkie przedstawione perspektywy, w kontekście których rozpatruje się przestępstwa seksualne, w ich obrębie wyróżnia się :

- wykorzystywanie seksualne dzieci (pedofilię),

- zgwałcenie,

- molestowanie seksualne,

- zabójstwa na tle seksualnym,

- kazirodztwo.

\subsection{Pojęcia - dziecko i małoletni}

Konwencja o Prawach Dziecka, przyjęta 20 listopada 1989 roku przez Zgromadzenie Ogólne ONZ , przyjmuje, że pod pojęciem „dziecko”, należy rozumieć każdą istotę ludzką w wieku poniżej 18 lat, chyba, że zgodnie z prawem odnoszącym się do dziecka uzyska ono wcześniej pełnoletniość (art.1 Konwencji).

Polski ustawodawca posługuje się różnym aparatem pojęciowym: „dziecko”, „małoletni”, „pełnoletni”, „nieletni”, „młodociany”, a zakres znaczeniowy tych terminów w języku prawnym i prawniczym jest różny i nie powinny być one używane zamiennie.

W myśl przepisu art. $10 \$ 1$ k.c., pełnoletnim jest, kto ukończył lat osiemnaście. Przed osiągnięciem tego wieku małoletni może uzyi skać pełnoletniość przez zawarcie małżeństwa; nie traci jej w razie unieważnienia małżeństwa (art. $10 \$ 2$ k.c.). Zgodnie z art. 10 k.r.o.

\footnotetext{
${ }^{9}$ Por. Z. Товоr, O wykładni, dz. cyt., 3; M. Filar, Prawo i seks, dz. cyt., s. 6; www. kidprotect.pl, Świat Przyjazny Dzieciom (data dostępu 28.04.2016).
} 
zawarcie małżeństwa przez małoletniego jest możliwe za zgodą sądu opiekuńczego w przypadku kobiety, która ukończyła lat szesnaście, gdy z okoliczności wynika, że zawarcie małżeństwa będzie zgodne z dobrem założonej rodziny. Nabytej w ten sposób pełnoletniości nie można następnie utracić w razie unieważnienia małżeństwa czy rozn wodu. Zatem małoletni (w rozumieniu polskiego prawa cywilnego) to osoba, która nie ukończyła lat 18 i nie zawarła małżeństwa.

Pojęcie „nieletniego"(pojęcie pejoratywne) definiuje ustawa $z$ dnia 26 października 1982 roku o postępowaniu w sprawach nieletnich (tj.: Dz.U. 2014, poz. 382). Nieletnim, w rozumieniu art. $1 \$ 2$ pkt 1 tej ustawy, jest:

1) osoba w wieku do lat 18 (0-18 lat), u której zwalcza się demoralizację;

2) osoba w wieku 13-17 lat, która popełniła czyn karalny (czyli czyn zabroniony jako przestępstwo lub przestępstwo skarbowe albo określone w ustawie wykroczenie);

3) osoba, wobec której wykonuje się środki wychowawcze lub poprawcze, w wieku do 21 lat.

W Polsce wiek 17 lat jest generalnie granicą odpowiedzialności karnej. Osoba, która ukończyła 17 lat i narusza Kodeks karny (k.k.), Kodeks karny skarbowy (k.k.s.) lub Kodeks wykroczeń (k.w.), popełnia czyn zabroniony przez ustawę, który może być przestępstwem, przestępstwem skarbowym lub wykroczeniem (oczywiście, jeżeli jest poczytalna, itd.) (art. $10 \$ 1$ k.k.).

Wyjątkowo nieletni może ponosić odpowiedzialność karną w przypadkach, określonych w art. $10 \$ 2$ k.k. oraz w art. 13 i art. 94 ustawy o postępowaniu w sprawach nieletnich.

Zgodnie z przepisem art. $10 \$ 2$ k.k., nieletni, który po ukończeniu 15 lat dopuszcza się czynu zabronionego określonego enumeratywnie w tym przepisie (m.in. zabójstwa $\mathrm{z}$ art. $148 \$ 1$, 2 lub 3 k.k., zgwałcenia z art. $197 \$ 3$ lub 4 k.k.), może odpowiadać na zasadach określonych w Kodeksie karnym, jeżeli okoliczności sprawy oraz stopień rozwoju sprawcy, jego właściwości i warunki osobiste za tym przemawiają, a w szczególności, jeżeli poprzednio stosowane środki wychowawcze lub poprawcze okazały się bezskuteczne. 
Pojęcie „młodocianego" występuje natomiast zarówno w prawie karnym (także prawie karnym wykonawczym - art. 84 k.k.w.), jak i w prawie pracy. Młodociany - w prawie karnym to osoba, która w chwili popełnienia czynu zabronionego nie osiągnęła 21 roku życia i w chwili orzekania przed sądem pierwszej instancji nie osiągnęła 24 roku życia (art. $115 \$ 10$ k.k.). Młodocianym, według Kodeksu pracy, jest osoba, która ukończyła 16 lat, a nie ukończyła 18 lat. Ma to znaczenie ze względu na szczególną ochronę pracy młodocianych (art. 190-206 k.p.).

Warto też zwrócić uwagę, że tzw. Reguły Pekińskie, których częścią są Wzorcowe Reguły Minimalne Narodów Zjednoczonych Dotyczące Wymiaru Sprawiedliwości Wobec Nieletnich, w pkt 4.1 zawierają postulat, aby w ustawodawstwach posługujących się pojęciem wieku, od którego rozpoczyna się odpowiedzialność karna nieletnich, dolna granica nie powinna być ustalona zbyt nisko, pamiętać bowiem trzeba o kwestiach dojrzałości emocjonalnej, umysłowej i intelektualnej. Trafnie zatem zwraca się uwagę na to, że dziecko z psychologicznego punktu widzenia nie jest tylko "miniaturą dorosłego".

Pierwszym prawnikiem, który zauważył konieczność zastosowania psychologii do oceny zeznań świadków był H. Gross, który wskazywał na celowość wzywania biegłych psychologów w trudnych przypadkach.

Rozwój prawa i psychologii przyczynił się w ogóle do tego, że dzieci i kobiety mogły występować w charakterze świadków (dawniej nie miały one takiego uprawnienia).

Dziecko pozostaje pod szczególną ochroną prawa karnego. Może ono bowiem stać się pokrzywdzonym szeregiem przestępstw przewidzianych w Kodeksie karnym, w tym przestępstw przeciwko wolności seksualnej i obyczajności (m.in. art. 197 k.k. - zgwałcenie i wymuszenie czynności seksualnej, art. 200 k.k. - seksualne wykorzystanie małoletniego, art. 200a k.k. - elektroniczna korupcja seksualna małoletniego, art. 220b k.k. - propagowanie pedofilii, art. 201 k.k. - kazirodztwo, art. $202 \$ 3,4$, 4a-4c k.k. - pornografia z udziałem małoletniego, art. 203 k.k. - zmuszenie do uprawiania prostytucji, art. 204 k.k. - stręczycielstwo, sutenerstwo i kuplerstwo 
dotyczące małoletniego jako osoby uprawiającej prostytucję, art. 207 k.k. - znęcanie, art. 208 k.k. - rozpijanie małoletniego, art. 209 k.k. niealimentacja, art. 210 k.k. - porzucenie małoletniego, art. 211 k.k. uprowadzenie małoletniego, art. 21la k.k. - organizowanie adopcji wbrew przepisom ustawy).

Dziecko - ofiara przestępstwa - jest stroną postępowania karnego, $\mathrm{z}$ tym, że jego uprawnienia procesowe są w praktyce realizowane przez przedstawicieli ustawowych.

Podstawą prawną, w oparciu o którą, lekarz ma obowiązek zawiadomić prokuraturę lub policję o wykorzystaniu seksualnym dziecka jest art. 304 Kodeksu postępowania karnego (k.p.k.). Zgodnie z tym przepisem, każdy dowiedziawszy się o popełnieniu przestępstwa ściganego z urzędu ma społeczny obowiązek zawiadomić o tym prokuratora lub Policję (art. $304 \$ 1$ k.p.k.). Instytucje państwowe i samorządowe, które w związku ze swą działalnością dowiedziały się o popełnieniu przestępstwa ściganego $z$ urzędu, są obowiązane niezwłocznie powiadomić o tym prokuratora lub Policję oraz przedsięwziąć niezbędne czynności do czasu przybycia organu powołanego do ścigania przestępstw lub do czasu wydania przez ten organ stosownego zarządzenia, aby nie dopuścić do zatarcia śladów i dowodów przestępstwa (art. $304 \$ 2$ k.p.k.).

\subsection{Podsumowanie}

Skomplikowana jest geneza zła, jakim jest przemoc seksualna wobec dziecka, skomplikowana jest jego istota. Rozważając te kwestie, należy pamiętać, że wyraża się tu dramat osób (dramatis personae): nie tylko osoby ofiary (victims), ale i dramat osoby sprawcy (perperatos) molestowania seksualnego dzieci. Zagadnienie to ma też głęboki kontekst dziejowy. W dziejach niejednokrotnie błędnie pojmowana wolność w sprawach płci była przyczyną zła. Również w tej materii jakże znamiennie brzmią słowa kardynała Stefana Wyszyńskiego: „Trzeba się uchronić przed dewaluacją osoby ludzkiej”. Seksualność człowieka jest jednym $\mathrm{z}$ jego podstawowych dóbr, w akcie przemocy, dobro to, jest niszczone, deprawowane. Rozmiary i ciężar krzywd wobec niewinnych dzieci są ogromne, a krzywdy te pokazują się 
w coraz to nowszych sferach życia dorastającego dziecka. Dziecko jest osobą i ma swoją godność, która (...) winna być szanowana-przemoc seksualna wobec dziecka uderza w godność osoby dziecka, ale i jego niewinność, jakkolwiek ją w kontekście psychoanalizy Freudowskiej rozumieć. Wykorzystywanie seksualne dziecka jest złem - jako najgorsza forma ich krzywdzenia nigdy nie może stać się rodzajem „zakazanej normy”10.

Seksualności człowieka nie można rozważać bez uwzględnienia obok uwarunkowań somatycznych, biopsychospołecznych, etyki seksualnej, wielkich dzieł Jana Pawła II, Józefa Tischnera, czy innych znanych etyków ${ }^{11}$.

\section{Aspekt kanoniczny przemocy seksualnej wobec małoletnich}

W tej części opracowania zostaną poruszone zagadnienia związane z przemocą seksualną wobec małoletnich z punktu widzenia prawa kanonicznego. Zostaną poddane analizie przepisy kościelne, które $\mathrm{z}$ jednej strony definiują przestępstwa w tej materii, określają ofiary nadużyć i wskazują duchownych jako sprawców, a drugiej strony te surowe unormowania pokazują rzeczywistą wolę Kościoła walki z przemocą wobec małoletnich i troskę o nich. Dwa przestępstwa będą w kręgu niniejszych rozważań a wynikające z kan. $1395 \$ 2$

${ }^{10}$ Por. Z. Lew- Starowicz, Seksuologia sądowa, dz. cyt., s. 229-231; G. JARZĄBek-Bielecka, J. Buks, D. Lorkiewicz-Muszyńska, M. ŁabęCKa, M. Jarząbek, A. Bielecka-Gąszcz, M. Wilczak, M. Pisarska-Krawczyk, T. Opala, Crimes against minors, sexual offenses, Pol. Prz. Nauk Zdr., 2014, nr 2, s. 176-181; G. JARZĄBeK-BieleckA, Health promotion..., dz. cyt., s. 39-42; G. JARZĄBeK-BieleckA, M.Jarząbek, M. Kownacka, A. Bielecka-Gąszcz., Z. Jarząbek, M. BorowCzyk, A. Chmielarz-Czarnocińska, K. Stachewicz, E. Sowińska-PrzePiera, W. KęDzia, Legal, psychologic..., dz. cyt., s. 78-79.

${ }^{11}$ Por. G. JarząBek-Bielecka, J. Buks, D. Lorkiewicz-Muszyńska, M. ŁabęCKa, M. Jarząbek, A. Bielecka-Gąszcz, M. Wilczak, M. Pisarska-Krawczyk, T. Opala, Crimes against minors..., dz. cyt., s. 176-181; G. JARZĄBEK-BieleCKA, Health promotion..., dz. cyt., s. 39-42; G. JARZĄBeK-BIElecka, M.JARZĄBEK, M. KownACKa, A. Bielecka-Gąszcz., Z. Jarząbek, M. Borowczyk, A. Chmielarz-Czarnocińska, K. Stachewicz, E. Sowińska-Przepiera, W. KęDzia, Legal, psychologic..., dz. cyt., s.78-79. 
KPK, z Norm De gravioribus delictis z 2001 oraz Norm De delictis reservatis $\mathrm{z} 2010$ roku.

\subsection{Rodzaje przestępstw wobec małoletnich i sankcje karne}

Wśród szerokiej gamy przestępstw rozważanych w kategoriach ciężkich przestępstw i zarezerwowanych Kongregacji Nauki Wiary są dwa przestępstwa związane z naruszeniem szóstego przykazania Dekalogu to jest: przestępstwo molestowania seksualnego małoletniego oraz przestępstwo pornografii dziecięcej. One staną się przedmiotem poniższej refleksji od strony podmiotowej i przedmiotowej przestępstwa oraz sankcji karnej.

\subsubsection{Molestowanie seksualne - pojęcie i strona przedmiotowa}

$$
\text { przestępstwa }
$$

Kanon $1395 \$ 2$ stanowi: Duchowny, który w inny sposób, wykroczył przeciwko szóstemu przykazaniu Dekalogu, jeśli jest to połączone $\mathrm{z}$ użyciem przymusu lub gróźb, albo publicznie lub z osobą małoletnią poniżej lat szesnastu, powinien być ukarany sprawiedliwymi karami, nie wyłączając w razie potrzeby wydalenia ze stanu duchownego". Przytoczony kanon zdaje się sugerować, że przestępstwami są wszystkie możliwe naruszenia szóstego przykazania, które będą mieć przynajmniej jedno ze wspomnianych $\mathrm{w}$ kanonie znamion, czyli bez spełnienia tego warunku nie można mówić o przestępstwie w sensie ścisłym.

Przymus o którym mówi kanon, oznacza zarówno gwałt, jak i jakąkolwiek inną formę naruszenia integralności cielesnej innej osoby, oczywiście wbrew jej woli. Gwałt jest wtargnięciem przemocą w intymność płciową osoby, niezależnie od płci, przez duchownego. Należy zauważyć, że naruszenie szóstego przykazania Dekalogu $\mathrm{z}$ użyciem przymusu to nie tylko zgwałcenie, ale także inne formy przemocy cielesnej zaliczane do molestowania seksualnego ${ }^{12}$.

\footnotetext{
${ }^{12}$ Por. J. Syry Jczy K, Kanoniczne prawo karne, część szczególna, Warszawa 2003, s. 164; D. Borek, Sextum Decalogi praeceptum w kanonicznym prawie karnym aktualnie obowiązującym, Biblios, Tarnów 2015, s. 73.
} 
Grożenie osobie pokrzywdzonej to kolejny sposób przestępnego działania uwzględniony przez KPK. Duchowny aby zmusić małoletnią osobę do podejmowania czynów skierowanych przeciwko czystości stosuje przymus psychiczny, zawierający w sobie niebezpieczeństwo wielkiego zła w przypadku odmowy ze strony ofiary przestępstwa. Sprawca może grozić np. takimi konsekwencjami, jak zniesławienie, czy wyrządzenie szkód. W przypadku przymusu psychicznego małoletni będąc ofiarą przestępstwa decyduje się sam na zaspokojenie roszczeń duchownego z obawy przed groźbą wyrządzenia jej jakiegoś zła. Jest to sytuacja ograniczonego wyboru, w przeciwieństwie do jego braku w sytuacji przymusu fizycznego ${ }^{13}$.

Kolejny sposób popełnienia przestępstwa uwzględniony w kan. $1395 \$ 2$ to publiczne, publice, wykroczenie przeciwko szóstemu przykazani Dekalogu. Wymaga się, aby zostało popełnione w obecności większej liczby osób albo skierowane do wielu odbiorców przez środki społecznego przekazu lub też było popełnione w miejscu publicznym albo otwartym dla publiczności, takim jak plac, ulica, kino, telewizja, Internet czy im podobne ${ }^{14}$. Należy tu także uwzględnić ekshibicjonizm, którego świadkami mogą być np. osoby małoletnie. Publiczne działanie duchownego winno być wynikiem działania świadomego i dobrowolnego ${ }^{15}$.

Przestępstwo, które nas wprost interesuje z kan. $1395 \$ 2$ dotyczy wszystkich czynów natury seksualnej popełnianych przez duchownego z osobami małoletnimi. Polega ono na naruszeniu szóstego przykazania ściśle z osobą małoletnią ${ }^{16}$. Kodeksowy zapis dotyczy

\footnotetext{
${ }^{13}$ Por. D. Borek, Sextum Decalogi..., dz.c yt., s. 74-75.

${ }^{14}$ Por. A. Calabrese, Diritto penale canonico, Città del Vaticano 1996, s. 281.

${ }^{15}$ Por. J. Syry Jczy K, Kanoniczne prawo karne..., dz. cyt., s. 164-165; B.F. Pighin, Diritto penale canonico, Venezia 2008, s. 476-477.

${ }^{16}$ Por. P. Сімвоціс, The identification and treatment of sexual disorders and the priesthood, The Jurist 52 (1992), s. 598-614; J. P. BEAL, Doing what one can: canon law and clerical sexual misconduct, The Jurist 52 (1992), s. 642-683; J. TouHEY, The correct interpretation of canon 1395: the use of the sixth commandment in the moral tradition from Trent to the present day, The Jurist 55 (1995), s. 592-631; J. H. Provst, Offences against the sixth commandment: toward a canonical analysis of canon 1395, The Jurist
} 
małoletnich poniżej szesnastego roku życia. Na zaistnienie przestępstwa nie wpływa to, czy małoletni zgadza się na czynności nieskromne, czy wyraża sprzeciw, czy jest świadomy lub nieświadomy znaczenia wydarzeń. Także płeć małoletniego nie zmienia faktu, że jest to przestępstwo. Akty przestępne wyrażają intencję sprawcy: wykorzystania nieletniego dla uzyskania jakieś stymulacji czy gratyfikacji seksualnej. Nadużycie posiada różne możliwe formy: dotyk, pocałunek w usta, ekspozycja organów płciowych lub sam stosunek seksualny. Istnieje też nadużycie niebezpośrednie: prowokująca rozmowa duchownego z nieletnim, czy posiadanie przez tegoż pierwszego materiałów pornograficznych, lub fotografowanie czy filmowanie nieletnich w celach pornograficznych ${ }^{17}$. Sam duchowny często występuje w relacji duszpasterskiej do małoletniego ${ }^{18}$. Czyny przestępne przedstawione $\mathrm{w}$ kan. $1395 \$ 2$ podlegają karaniu nawet wtedy, gdy zostały popełnione jednorazowo. Nadużycia seksualne wobec małoletnich naruszają ich godność ludzką i wolność osobistą.

\subsubsection{Strona podmiotowa przestępstwa [podmiot czynny i bierny]}

Sprawcą przestępstwa, czyli podmiotem czynnym, związanego z molestowaniem seksualnym, w myśl kan. $1395 \$ 2$ KPK, Norm z 2001 roku i art. $6 \$ 1$, nr 2 Norm z 2010 roku jest wyłącznie osoba duchowna (clericus), czyli diakon ${ }^{19}$, kapłan lub biskup. To oznacza, że $\mathrm{w}$ prawie kanonicznym nastąpiła rezygnacja z nadania omawianemu

55(1995), s. 632-663; R. JENkIns, On the suitability of establishing clerical sexual abuse of minors (c. $1395 \$ 2$ ) as an irregularity ex delicto to the reception and exercise of orders, Periodica 94(2005), s. 275-340; Z. SUCHECKI, La tutela dei minori presso la Congregazione per la Doctrina della Fede riguardo ai delicta graviora, Appolinaris 3-4(2006), s. 719-732; D. Albornz, Norme e orientamenti della Chiesa cattolica dinanzi agli abusi sessuali di minori perpetrati da chierici, Salesianum 70(2008), s. 713-71; A. DomAszk, Reakcja Kościoła na nadużycia seksualne wobec nieletnich ze strony duchownych, Seminare t. 31(2012), s. 75.

${ }^{17}$ Por. D. Albornoz, Norme e orientamenti..., dz. cyt., s. 716.

${ }^{18}$ Wykorzystanie godności, władzy czy urzędu dla popełnienia przestępstwa wymaga surowszego ukarania, por. KPK, kan. $1326 \$ 1 \mathrm{nr} 2$.

${ }^{19}$ Będzie chodziło tutaj zarówno o diakonów do prezbiteratu, jak i o diakonów stałych, por. kann. 236; 1031 i 1032 KPK. 
przestępstwu znamienia uniwersalności i traktuje się nadużycia tego typu jako delicta propria, czyli tylko do określonej kategorii osób w Kościele ${ }^{20}$. W pojęciu duchownego nie mieszczą się ani wierni konsekrowani przez profesję rad ewangelicznych, którzy nie przyjęli święceń, ani tym bardziej wierni świeccy ${ }^{21}$. W przypadku czynów molestowania seksualnego, przez nieposiadających święceń członków insty tutów zakonnych, członków instytutów świeckich i stowarzyszeń życia apostolskiego, kompetentny ordynariusz powinien zastosować ogólne zasady postępowania, wynikające z kanonów 695, 729 i $746 \mathrm{KPK}^{22}$. Z kolei wyłączenie się wiernego świeckiego z podmiotów czynnych molestowania seksualnego - wprawdzie nie stanowi czynu karalnego na mocy przepisów prawa kanonicznego - to jednak, jeśli za to został skazany przez władze świeckie, może być to zjawisko uznane za 'słuszną przyczynę' skłaniającą kompetentną władzę kościelną np. do odwołania misji kanonicznej bądź usunięcia $\mathrm{z}$ urzędu ${ }^{23}$.

Rozumienie przez pojęcie clericus - duchowny, jako podmiot czynny przestępstwa molestowania seksualnego lub przestępstw przeciwko czystości w świetle Kodeksu Kanonów Kościołów Wschodnich (kan. 325, 327) i Norm z 2010 domaga się pewnego dopowiedzenia. W świetle wymienionych dokumentów przestępstwo to mogą bowiem, obok diakonów, kapłanów lub biskupów, popełnić także osoby, które mają święcenia niższe np. subdiakonat, jeśli jest to zgodne z prawem własnym Kościoła sui iuris uznawanych w jego prawie partykularnym za osobę duchowną. Zatem osoba niższych święceń,

\footnotetext{
${ }^{20}$ Por. F. LEMPA, Kanoniczna ochrona małoletnich przed nadużyciami seksualnymi, Białystok 2013, s. 59; J. Sowı́́sKi, Nabycie, przechowywanie lub rozpowszechnianie pornografii dziecięcej przez duchownego jako jedno z przestępstw kanonicznych zarezerwowanych dla Kongregacji Nauki Wiary, Prawo i Kościół, t. 8, 2016, s. 79.

${ }^{21}$ Por. Kan. 207 KPK.

${ }^{22}$ Por. D. BoreK, Delicta graviora contra mores $w$ Normach de delictis reservatis z 2010 roku, Prawo Kanoniczne 57(2014) nr 2, s. 62; J. SŁow IŃski, Nabycie..., dz. cyt., s. 80 .

${ }^{23}$ Por. J. Dohnalik, Prawo kanoniczne wobec nadużý seksualnych duchownych względem dzieci i młodzieży, Dziecko krzywdzone, Teoria, badania, praktyka 14(2015) nr 1, s. 55.
} 
jeśli jest uznawana za osobę duchowną $\mathrm{w}$ prawie własnym, popełnia też przestępstwo penalizowane przez prawo kanoniczne i zarezerwowane Kongregacji Nauki Wiary ${ }^{24}$.

Podmiotem biernym przestępstwa molestowania seksualnego, czyli ofiarą, w przepisach kodeksowych był małoletni poniżej szesnastego roku życia, niezależnie do płci osoby i od postawy będącej przedmiotem przestępstwa. Tak więc nie miało tutaj znaczenia, czy osoba małoletnia dobrowolnie i spontanicznie zgadza się na dany czyn seksualny, czy sama go sprowokowała lub czy też wszystko odbyło się wbrew jej woli. Ponadto niekoniecznie musiał być kontakt fizyczny duchownego z małoletnią osobą, wystarczy, że duchowny podjął działania zmierzające do wykorzystania małoletniego w celu uzyskania podniety seksualnej lub zaspokojenia seksualnego ${ }^{25}$. Przedmiotem ochrony jest małoletni jako taki, dlatego też przestępstwo należy uznać za dokonane niezależnie od postawy osoby małoletniej. Ustawodawca w KPK w kwestii wieku był wymagający, bo przecież według ustawodawcy państwowego polskiego obcowanie z osobą powyżej 15 roku życia nie stanowi już przestępstwa. Wiek w prawodawstwie kościelnym został jeszcze wyżej podniesiony by chronić większą liczbę małoletnich i mając na uwadze szczególny ciężar przestępstwa w tej materii. Otóż w Normach De gravioris delictis z 2001 roku, a następnie w Normach De delictis reservatis z 2010 roku, podniesiono wiek ofiary przestępstwa do ukończenia 18 roku życia ${ }^{26}$. Należy więc najpierw zauważyć, że wykroczenia duchownego przeciwko szóstemu przykazaniu Dekalogu z małoletnim pomiędzy 16 a 18 rokiem życia do wejścia w życie Norm De gravioribus delictis z 2001 roku nie było

\footnotetext{
${ }^{24}$ Por. J. SŁowiński, Nabycie..., dz. cyt., s. 81; F. Lempa, Kanoniczna ochrona..., dz. cyt., s. 60 .

${ }^{25}$ Por. D. Albornz, Norme e orientamenti..., dz. cyt., s. 714-715.

${ }^{26}$ Por. Joannes Paulus II, Litterae Apostolica motu proprio datae qubis Normae de gravioribus delictis Congregationi pro Doctrina Fidei reservatis promulgatur, Sacramentorum Sanctitatis Tutela, 30 aprilis, AAS 93(2001), s. 737-739; Congregatio Pro Doctrina Fidei, Normae de delictis Congregationi pro Doctrina Fidei reservatis seu Normae de delictis contra Fidem necnon de gravioribus delictis (21.05.2010), AAS 102 (2010), s. 419-430.
} 
przestępstwem kanonicznym. Następnie czyny duchownego wobec małoletnich mogą być zakwalifikowane jako pedofilskie (do 13 roku życia) lub efebofilskie (między 14-18 rokiem). Według znawców tej problematyki najczęściej zdarzają się akty efebofilii2 ${ }^{27}$. Przestępstwo seksualnego wykorzystania małoletnich, czy to pod postacią pedofilii, czy też efebofilii, stanowi jeden z poważniejszych problemów współczesnego Kościoła.

Normy De delictis reservatis z 2010 roku zrównały z osobą małoletnią osobę, która habitualnie posiada niepełne używanie rozumu, co stanowi nowość w zakresie podmiotów biernych omawianego przestępstwa ${ }^{28}$. Zatem nie wymaga się, aby osoba, która jest ofiarą molestowania seksualnego przez duchownego była całkowicie pozbawiona używania rozumu, wystarczy, że u tej osoby procesy intelektualne i wolitywne były częściowo niesprawne. Natomiast do zaistnienia przestępstwa prawodawca kościelny domaga się trwałego charakteru niesprawności intelektualnej, nawet jeśli zdarzają się tzw. lucida intervalla. Przejściowej niedyspozycji np., nadużycie alkoholu czy narkotyków, nie można wiązać z przybliżanym przestępstwem molestowania seksualnego osoby zrównanej z małoletnim ${ }^{29}$.

\subsubsection{Sankcje karne}

Przestępstwo we wszelkiej formie molestowania seksualnego popełnione przez duchownego wobec osoby poniżej 18 roku życia lub wobec osoby, która habitualnie posiada niepełne używanie rozumu dokonuje się na skutek winy umyślnej. Jak wynika bowiem

\footnotetext{
${ }^{27}$ Por. G. Versaldi, Aspetti psicologici degli abusi sessuali perpetrati da chierici, Periodica 91(2002), s. 49-61.

${ }^{28}$ Art. 6. „\$1 n.1 delictum contra sextum Decalogi praeceptum cum minore infra aetatem duodeviginti annorum a clerico commissum; in hoc numero minori aequiparatur persona quae imperfecto rationis usu habitu pollet" . Congregatio Pro Doctrina Fidei, Normae de delictis Congregationi pro Doctrina Fidei reservatis..., dz. cyt., s. 424.

${ }^{29}$ Por. C. Papale, I delicti contro morale, w: Questioni attuali di diritto penale canonico, Studi Giuridici 96, Cittá del Vaticano 2012, s. 56; D. BoreK, Delicta graviora, dz. cyt., s. 60-61.
} 
z dyspozycji zawartej w kan. $1321 \S 2$ karalności z zasady podlegają jedynie przestępstwa popełnione ex dolo, natomiast karalność przestępstw z winy nieumyślnej, czyli popełnionych ex culpa, jest możliwa wyjątkowo i tylko wtedy, gdy to przewiduje ustawa karna bądź nakaz karny. W przypadku delicta contra mores nie mówi się nic na temat ewentualnej karalności w sytuacji, gdyby doszło do omawianych form naruszenia na skutek winy nieumyślnej.

Sankcją karną, jaką przewiduje KPK w kan. 1395 \$ 2 i konsekwentnie późniejsze akty prawne Stolicy Apostolskiej, to kara ferendae sententiae obowiązkowa nieokreślona z możliwością zastosowania nawet wydalenia ze stanu duchownego. Środkami karnymi mogą być ograniczenia publicznej posługi kapłańskiej, zakazy kontaktu z niepełnoletnimi, nakazy karne po myśli kan. 1319 KPK i inne sankcje karne. Niemniej jednak należy zaznaczyć, że w myśl kan. 1244, nr 2 sędzia może powstrzymać się od wymierzenia kary albo też wymierzyć łagodniejszą w sytuacji, gdy sprawca przestępstwa duchowny został już ukarany przez władzę świecką. Wobec duchownych zakonników jest dość złożona prassi Kongregacji Nauki Wiary, podobnie jak wobec zakonnika nieposiadającego święceń, który popełnił omawiane wyżej przestępstwo ${ }^{30}$. Jednak pozostając w zgodzie z kan. $18 \mathrm{KPK}$, który domaga się zastosowania ściślej interpretacji ustaw karnych, należy stwierdzić, że kan. $1095 \$ 2$ i Normy z 2010 roku nie mają zastosowania w przypadku, gdyby wykroczenia przeciwko szóstemu przykazaniu Dekalogu z osobą małoletnią dopuścił się zakonnik, który nie posiada święceń, albo wierny świecki pełniący jakąś misję w imieniu Kościoła ${ }^{31}$.

\subsubsection{Przestępstwo pornografii dziecięcej}

Drugą postacią przestępstwa, zarezerwowaną Kongregacji Nauki Wiary, jest pornografia dziecięca. Na uwagę zasługuje to, że

\footnotetext{
${ }^{30}$ Por. D. Borek, Sextum Decalogi..., dz. cyt., s. 97-99.

${ }^{31}$ Por. Ch.J. Scicluna, Procedura e prassi presso la Congregazione per la Dottrina della Fede riguardo ai delicta graviora, w: Processo penale e tutela dei diritti nell'ordinamento canonico, red. D. Cito, Milano 2005, s. 286-288.
} 
wprawdzie pornografia dziecięca została uznana za odrębne przestępstwo dopiero w normach De delictis reservatis z $2010 \mathrm{roku}$, niemniej jednak już od promulgacji norm z 2001 roku Kongregacji Nauki Wiary zaliczała do przestępstw przeciwko obyczajom także pornografię dziecięcą ${ }^{32}$. Poprzez motu proprio Sacramentorum sanctitatis tutela Kongregacja Nauki Wiary uznawała za przestępstwo przeciw obyczajom ściąganie (downloading) pornografii dziecięcej przez osoby duchowne ${ }^{33} \mathrm{~W}$ tym miejscu jednak należy przypomnieć, że Kościół katolicki widział wraz z rozwojem nowych technologii, niebezpieczeństwo traktowania istot ludzkich nie jako osób, ale jako rzeczy, w tym poprzez pornografię. Papieże XX wieku (Paweł VI, Jan Paweł II) podkreślali potrzebę tworzenia klimatu sprzyjającego czystości i potępiali wszystkie formy pornografii i nieprzyzwoitych widowisk oraz to wszystko, co łączyło się z traktowaniem osoby jako przedmiotu kupna-sprzedaży ${ }^{34}$. Wyraźne określenie i potępienie pornografii ze strony Urzędu Nauczycielskiego Kościoła znajduje się w Katechizmie Kościoła Katolickiego. Oto one: „Pornografia polega na wyrwaniu aktów płciowych, rzeczywistych lub symulowanych, z intymności partnerów, aby w sposób zamierzony pokazać je innym. Znieważa ona czystość, ponieważ stanowi wynaturzenie aktu małżeńskiego, wzajemnego intymnego daru małżonków. Narusza poważnie godność tych, którzy się jej oddają (aktorzy, sprzedawcy, publiczność), ponieważ jedni stają się dla drugich przedmiotem prymitywnej przyjemności i niedozwolonego zarobku. Przenosi ona ich wszystkich w świat iluzoryczny. Pornografia jest ciężką winą. Władze cywilne powinny zabronić wytwarzania i rozpowszechniania

\footnotetext{
${ }^{32}$ Por. D. Borek, Sextum Decalogi..., dz. cyt., s. 116; CH. J. Scicluna, Procedura e prassi..., dz. cyt., s. 282-283.

${ }^{33}$ Por. Joannes Paulus II, Sacramentorum..., dz. cyt., s. 737-739; także, J. SŁow IŃSki, Nabycie...., dz. cyt., s. 78; C. PAPALE, I delitti contro la morale, w: A. D'auria, C. P Apale (red.), I delitti riservati alla Congregazione per la Dottrina delle Fede, Quaderni di Ius Missionale, Roma 2014, s. 34.

${ }^{34}$ Por. Paulus VI, Littera Encyclica Humanae vitae (25.07.1968), AAS 60(1968), nr 22; Joannes Paulus II, Adhortatio apostolica Familiaris consortio (22.11.1981), AAS 74(1982), nr 24.
} 
materiałów pornograficznych"35. W tym miejscu należy podkreślić i przypomnieć, że w doktrynie odróżnia się pedofilię od efebofilii. W przypadku pedofilii będziemy mówić o nadużyciach seksualnych w stosunku do dzieci przed pokwitaniem (aż do 13 roku życia), natomiast w stosunku do małoletnich pomiędzy 14 al7 rokiem będziemy mieli do czynienia $z$ efebofilią ${ }^{36}$. Przestępstwo pornografii dziecięcej wiążę się z pedofilią ${ }^{37}$ bowiem Kongregacja Nauki Wiary w tekście Norm z 2010 roku dotyczących cięższych przestępstw w artykule $6 \$ 1$, nr 2 tak stanowi: „\$1. Najcięższymi przestępstwami przeciw obyczajom, które osądza tylko Kongregacja Nauki Wiary, są: [...] $2^{\circ}$ nabywanie albo przechowywanie, lub rozpowszechnianie w celach lubieżnych materiałów pornograficznych, przedstawiających nieletnich poniżej czternastego roku życia, przez duchownego - w jakikolwiek sposób i za pomocą jakiegokolwiek urządzenia”. Zgodnie z powyższym określeniem przestępstwa należy odnieść się do niego najpierw od strony podmiotowej, a następnie od strony przedmiotowej.

\subsubsection{Strona podmiotowa przestępstwa}

Sprawcą przestępstwa, czyli podmiotem czynnym, związanego $\mathrm{z}$ dziecięcą pornografią, w myśl cytowanego art. $6 \$ 1$, nr 2 Norm z 2010 roku jest wyłącznie osoba duchowna (clericus), czyli diakon, kapłan lub biskup. Także osoby, które mają święcenia niższe np. subdiakonat, jeśli jest to zgodne z prawem własnym Kościoła sui iuris uznawanych w jego prawie partykularnym za osobę duchowną świetle

\footnotetext{
${ }^{35}$ Katechizm Kościoła Katolickiego, Pallottinum Poznań 1994, nr 2254; por. M. SAJ, Ochrona osób małoletnich w kanonicznym prawie karnym, Ateneum Kapłańskie 167(2016), z. 1(644), s. 65.

${ }^{36}$ Por. G. Versaldi, Aspetti psicologici..., dz. cyt., s. 49-61; F. Quattrini, Parafilie e devianza. Psicologia e psicopatologia del comportamento sessuale atipico, Firenze 2015, s. 139.

${ }^{37}$ Więcej na temat definicji psychiatrycznej pedofilii zob. T. Wytrwa£, Kościelny modus procedendi w przypadku pedofilii, Prawo Kanoniczne 52(2009) nr 1-2, s. 233-235.
} 
$\mathrm{KKKW}^{38}$. W pojęciu duchownego - jak to już wyżej zaznaczono - nie mieszczą się ani wierni konsekrowani przez profesję rad ewangelicznych, którzy nie przyjęli święceń, ani tym bardziej wierni świeccy ${ }^{39}$. W przypadku użytkowników pornografii dziecięcej, będących nieposiadającymi święceń członkami instytutów zakonnych, członków instytutów świeckich i stowarzyszeń życia apostolskiego, kompetentny ordynariusz powinien zastosować ogólne zasady postępowania, wynikające z kanonów 695, 729 i $746 \mathrm{KPK}^{40}$. Z kolei włączenie się wiernego świeckiego w obieg dziecięcej pornografii - wprawdzie nie stanowi czynu karalnego na mocy art. $6 \$ 1 \mathrm{nr} 2$ Norm z roku 2010 to jednak, jeśli za to został skazany przez władze świeckie, może być to zjawisko uznane za 'słuszną przyczynę' skłaniającą kompetentną władzę kościelną do odwołania misji kanonicznej, bądź usunięcia $\mathrm{z}$ urzędu ${ }^{41}$.

Podmiotem biernym, ofiarą, przestępstwa pornografii dziecięcej jest osoba małoletnia, poniżej 14 roku życia, bez względu na jej płeć. W tym kontekście pornografia dziecięca oznacza zdjęcia lub filmy zawierające akty seksualne z małoletnimi, poniżej 14 roku życia albo pomiędzy takimi małoletnimi, lub też zawierające obrazy ww. małoletnich w pozycjach lub zachowaniach zmierzających do wywołania zainteresowania (pobudzania) seksualnego u osób oglądających te obrazy $^{42}$. Słusznie podkreśla się, że aby zaistniało omawiane przestępstwo, materiał pornograficzny musi dotyczyć małoletnich poniżej 14 roku oraz zdarzeń, które rzeczywiście miały miejsce. Musi więc chodzić o fotografie i filmy, na których utrwalono rzeczywiste zdarzenia, a osoby w nich uczestniczące nie zostały sztucznie wytworzone. Stąd nie wyczerpuje znamion przestępstwa użytkowanie materiałów

\footnotetext{
${ }^{38}$ Por. J. SŁowiŃski, Nabycie..., dz. cyt., s. 81; F. LempA, Kanoniczna ochrona..., dz. cyt., s. 60.

${ }^{39}$ Por. Kan. 207 KPK.

${ }^{40}$ Por. D. Borek, Delicta graviora..., dz. cyt., s. 62; J. SŁowiński, Nabycie..., dz. cyt., s. 80.

${ }^{41}$ Por. J. Dohnalik, Prawo kanoniczne wobec nadużyć seksualnych..., dz. cyt., s. 55 .

${ }^{42}$ Por. C. Papale, I delicti contro morale..., dz. cyt., s. 59.
} 
pornograficznych przedstawiających namalowane, narysowane lub stworzone cyfrowo dzieci poniżej 14 lat. Nie popełnia przestępstwa duchowny użytkujący tzw. pedopornografię wirtualną, czyli dwu lub trzywymiarowe obrazy lub filmy stworzone w celu zaspokojenia pożądania seksualnego pedofilów i efebofilów. W wymienionych sytuacjach nie ma realnej ofiary, biernego podmiotu przestępstwa, stąd duchowny użytkownik takich materiałów nie może być karany, choć jego czyn ma bardzo ciężki wymiar moralny, grzeszny ${ }^{43}$. Ważną czynnością przy przestępstwie pornografii dziecięcej jest ustalenie wieku osób znajdujących się w materiałach pornograficznych, a to nie jest łatwe. Materiał ten musi dotyczyć osób poniżej 14 roku życia. Czy rzeczywiście w danym przypadku mamy do czynienia z małoletnim poniżej 14 lat, czy też nie, jest to oczywiste tylko przy małych dzieciach. Nie tylko z powodu trudności ustalenia wieku ofiary przestępstwa, pojawiają się sugestie, aby podwyższyć ten wiek poniżej 18 roku życia, ale także $\mathrm{z}$ innych racji. Nie bardzo zrozumiałym się wydaje bowiem ustalenie górnej granicy wieku na 14 lat życia, ponieważ tak samo złe są materiały pornograficzne dotyczące małoletnich w wieku lat 15, jak i tych w wieku lat 13. Każda pornografia narusza godność osoby niezależnie od osiągniętego wieku. Stąd postulaty kanonistów podwyższenia wieku do 18 lat wydają się sensowne. Byłoby to też spójne z przestępstwem molestowania seksualnego małoletnich ${ }^{44}$. Inny kanonista zwraca uwagę w związku z pornografią dziecięcą na to iż należałoby przemyśleć sprawę ewentualnej karalności dziecięcej pornografii wirtualnej wobec szalonego rozwoju technik cyfrowych, tak jak to czyni polski kodeks karny w art. $202 \S 4 b^{45}$.

\footnotetext{
${ }^{43}$ Por. J. SŁowiński, Nabycie..., dz. cyt., s. 83; D. Borek, Sextum Decalogi..., dz. cyt., s. 118.

${ }^{44}$ Por. A.G. Astigueta, Ultime modifiche al motu proprio delicta graviora, w: Il quindicesimo anniversario dell'istituto di diritto canonico"Ad instar facultas dell' Universitá Cattolica Pázmány Péter, red. Sz. A. Szuromi, Budapeszt 2011, s. 80; D. Borek, Sextum Decalogi..., dz. cyt., s. 117; J. SŁowiński, Nabycie..., dz. cyt., s. 84 .

${ }^{45}$ Por. J. SŁowiński, Nabycie..., dz. cyt., s. 84.
} 


\subsubsection{Strona przedmiotowa przestępstwa}

Zgodnie z Normami z 2010 roku przestępstwo pornografii dziecięcej od strony przedmiotowej może polegać na nabywaniu, przechowywaniu lub rozpowszechnianiu materiałów pornograficznych. Każdy ten sposób, $z$ trzech form, domaga się pewnego przybliżenia i wyjaśnienia, gdyż są one dość złożone w kontekście nowych technik. Pierwsza forma, czyli comparatio - nabywanie, to sytuacja, kiedy ktoś nabywa od osób trzecich, np. za pośrednictwem Internetu, materiały zawierające pornografię dziecięcą. Następstwem tej formy comparatio jest zwykle zapamiętanie otrzymanych materiałów w postaci plików w formacie cyfrowym, w pamięci komputera, tabletu lub telefonu, bądź na jakimś przenośnym nośniku danych (pendrive, DVD, karty pamięci, dysk przenośny itp). Aby zaistniało przestępstwo, osoba duchowna musi mieć świadomość, że nabywa materiał z pornografią dziecięcą i musi tego chcieć. Może bowiem się zdarzyć, że wspomniana comparatio materiałów z pornografią dziecięcą będzie wynikiem działania nieświadomego i w tym przypadku ściąganie z Internetu (download) nie może stanowić podstawy odpowiedzialności karnej ${ }^{46}$. Świadome działanie będzie miało miejsce wtedy, gdy duchowny dokonuje nabycia z użyciem karty kredytowej lub przelewu zapłaty.

Druga forma popełnienia przestępstwa kanonicznego to detentio, czyli przechowywanie materiałów pornograficznych z udziałem dzieci poniżej lat 14 przez duchownego. Sposoby przechowywania zakazanych materiałów zmieniają się w zależności od ich formatu: na dysku komputera, na nośniku pamięci zewnętrznej, na serwerze w sieci internetowej, w domu, w miejscu pracy, w sejfie albo innej skrytce. Istotne znamię tej formy przestępstwa stanowi fakt, że określony materiał pornograficzny jest do dyspozycji na każde

\footnotetext{
${ }^{46}$ Por. C. Papale, I delitti contro la morale..., dz. cyt., s. 36-37; M. Di Veroli, Pedopornografia: aspetti tecnico informatici utili all'accertamento delle responsabilità penali da parte dell'autore, w: C. Papale, I delitti riservati alla Congregazione per la Dottrina della Fede. Norme, prassi, obiezioni, Roma 2015, s. 131-159; J. SŁow IŃski, Nabycie..., dz. cyt., s. 86.
} 
żądanie, czego sprawca ma świadomość. Może się jednak zdarzyć, że detentio może być następstwem nieświadomego nabycia materiałów pornograficznych i dopiero po ich zobaczeniu osoba zachowuje je w celach lubieżnych ${ }^{47}$. Dla odpowiedzialności karnej duchownego nie będzie miał większego znaczenia fakt, że w pewnym momencie oskarżony pozbył się całości zabronionych materiałów, które przedtem przechowywał ${ }^{48}$.

Wreszcie ostatnią formą przybliżanego przestępstwa pornografii dziecięcej jest divulgatio, czyli rozpowszechnianie tych materiałów. Do jej zaistnienia jest konieczne, aby sprawca był w posiadaniu takich materiałów pornograficznych a następnie podjął działania umożliwiające ich udostępnienie (odpłatne lub bezpłatne) osobom trzecim, aby mogły z nich korzystać ${ }^{49}$. Bez znaczenia pozostaje rodzaj instrumentów technicznych i sposób rozpowszechniania, np. rozsyłanie pocztą, sprzedaż, wypożyczenie, darowizna, porzucenie materiałów w miejscu dostępnym dla osób postronnych, udzielenie dostępu osobom trzecim do własnego komputera itp. Pewną formą dystrybucji jest użytkowanie sieci peer to peer, gdzie użytkownicy ściągają nielegalne materiały od innych użytkowników. Otóż, jeśli pozyskujący w ten sposób nielegalne treści sam godzi się dobrowolnie na to, że z jego komputera mogą zostać skopiowane pliki zawierające materiały $\mathrm{z}$ pornografią dziecięcą, to może mieć miejsce świadome rozpowszechnianie zakazanych treści i może dojść do popełnienia przestępstwa kanonicznego ${ }^{50}$.

\subsubsection{Dolus specificus i sankcje karne}

Istotnym elementem wszystkich trzech form przestępstwa pornografii dziecięcej jest wina umyślna (dolus) po stronie osoby duchownej nabywającej, przechowującej lub też rozpowszechniającej treści

\footnotetext{
${ }^{47}$ Por. Z. Suchecki, La tutela penale..., dz. cyt., s. 723-724.

${ }^{48}$ Por. C. PApale, I delitti contro la morale..., dz. cyt., s. 43-44; J. Sowiński, Nabycie..., dz. cyt., s. 88.

${ }^{49}$ Por. D. Borek, Delicta graviora..., dz. cyt., s. 65-66.

${ }^{50}$ Por. J. SŁowiński, Nabycie..., dz. cyt., s. 89.
} 
pornograficzne z małoletnimi poniżej 14 roku życia. Wina umyślna oznacza wolę popełnienia czynu, prawnie unormowanego jako czyn przestępczy ${ }^{51}$. Należy jednak zaznaczyć, że w omawianym przestępstwie mamy do czynienia z dolus specificus. Nie wystarczy zatem, aby sprawca działał świadomie i dobrowolnie, ale konieczny jest specyficzny cel takiego działania, wskazuje na to bowiem użyte w normach z 2010 roku sformułowanie a clerico turpe patrata. Oznacza to, że każde z wyliczonych działań (tj. nabywanie, przechowywanie, rozpowszechnianie), chociaż ma różny ciężar, winno być dokonane przez duchownego w celach lubieżnych, ponieważ ów specyficzny cel jest konieczny. Ten cel lubieżny niekoniecznie musi być zaspokojony, natomiast przestępca winien kierować się celami lubieżnymi przy nabywaniu, posiadaniu i rozpowszechnianiu pornografii dziecięcej ${ }^{52}$. Z tego wynika, że jeśli duchowny popełni czyn związany z użytkowaniem pornografii dziecięcej w postaci jednej z form comparatio, detentio vel divulgatio, lecz celem czynu zabronionego nie będzie realizacja celów lubieżnych (własnych lub osób trzecich), nie ma mowy o karalności sprawcy.

W przypadku przestępstwa związanego z pornografią dziecięcą Normy z 2010 roku przewidują dla duchownego, podobnie jak przy przestępstwie molestowania seksualnego osobę małoletnią, karę ferendae sententiae do zaaplikowania stosownie do ciężaru przestępstwa, nie wykluczając wydalenia lub depozycji (art. 6, \$2). Okolicznościami wpływającymi na rodzaj sankcji będzie na pewno ilość materiałów pornograficznych z jakimi miał styczność oskarżony, częstotliwość i czas trwania działalności przestępczej, rodzaj materiałów pedopornograficznych, czyli stopień drastyczności treści, forma popełnienia przestępstwa i ewentualnie zgorszenie publiczne. Jest to jednak dość surowe potraktowanie duchownych jako sprawców przestępstwa pornografii dziecięcej. Owa surowość kary wydalenia lub

\footnotetext{
${ }^{51}$ Por. J. Sy Ry JCzy , Sankcje w Kościele. Część ogólna, komentarz, Warszawa 2008, s. 111-116.

${ }^{52}$ Por. C. Papale, I delitti contro la morale..., dz. cyt., s. 44, 64-65; D. Borek, Sextum Decalogi..., dz. cyt., s. 119; J. SŁowıŃski, Nabycie..., dz. cyt., s. 90-91.
} 
pozbawienia urzędu jest podyktowana tym, że pornografia dziecięca przyczynia się do ożywiania i umacniania 'przemysłu' zajmującego się produkcją tego rodzaju materiałów, tym samym rozwijając proceder wykorzystywania do tego celu dzieci ${ }^{53}$.

\subsection{Przedawnienie czynów kryminalnych wobec małoletnich}

Skarga z tytułu przestępstwa przeciwko szóstemu przykazaniu Dekalogu, w myśl kan. $1362 \$ 1$ punktu 2, przedawniała się zasadniczo po upływie pięciolecia, chociaż nie wszyscy byli tego zdania ${ }^{54}$. Natomiast Jan Paweł II za pośrednictwem motu proprio Sacramentorum sanctitatis tutela przedłużył okres przedawnienia czynu kryminalnego z 5 do 10 lat i określił, że czas ten będzie upływał od daty, kiedy nieletni osiągnie pełnoletniość, tj. skończy 18 lat. Na tym nie koniec ewolucji przepisów w tym względzie. Obowiązujące aktualnie przepisy co do przedawnienia czynów kryminalnych w myśl art. $7 \$ 1$ Norm de delictis reservatis z 2010 roku stanowią, że czyn molestowania seksualnego i przestępstwo pornografii dziecięcej przedawnia się po 20 latach od jego popełnienia, przy zachowaniu prawa Kongregacji Nauki Wiary do uchylenia tego przedawnienia. Liczy się ono zgodnie z kan. $1362 \$ 2 \mathrm{KPK}$, natomiast w przypadku przestępstwa, o którym w art. $6, \$ 1$, nr 1, czyli gdy chodzi o molestowanie seksualne przedawnienie zaczyna się liczyć od dnia, w którym nieletni skończył osiemnaście lat ${ }^{55}$. Tak długi czas, kiedy możliwe jest ściganie sprawcy i nałożenie na niego kary, pokazuje wolę Kościoła by chronić małoletnich przed nadużyciami seksualnymi i karać autorów tych przestępstw. Ponadto możliwość uchylania tych 20 lat przedawnienia jest wyraźnym znakiem woli Kościoła położenia kresu tym przestępstwom dokonywanych przez duchownych. Wymienione zasady przedawnienia skargi kryminalnej w przypadku przestępstw

\footnotetext{
${ }^{53}$ Por. D. Borek, Sextum Decalogi..., dz. cyt., s. 120-121.

${ }^{54}$ Por. M. SтокŁosA, Przedawnienie skargi kryminalnej w prawie kanonicznym, Prawo Kanoniczne 56(2013) nr 4, s. 149.

${ }^{55}$ Por. Art. 7 Normae de gravioribus delictis, dz. cyt.; M. SтокŁosA, Przedawnienie..., dz. cyt., s. 150-151.
} 
zarezerwowanych Kongregacji Nauki Wiary mają też zastosowanie do katolickich Kościołów wschodnich.

\subsection{Troska Kościoła o ochronę małoletnich}

Medialnie nagłaśniane nadużyć seksualnych popełnianych przez duchownych i zakonników wobec nieletnich sprawia wrażenie jakoby Kościół nie reagował na nie. To głośne i agresywne przesłanie mass mediów nie jest prawdą. Przegląd różnych wystąpień papieskich i ich dokumentów, jak również zaangażowanie Kurii Rzymskiej, a zwłaszcza Kongregacji Nauki Wiary, ukazuje wielopłaszczyznową i bardzo aktywną reakcję Kościoła.

Samo zjawisko molestowania seksualnego małoletnich przez duchownych było przedmiotem wielu przemówień papieży Jana Pawła II i Benedykta XVI, debat wewnątrz kongregacji rzymskich. Zostało ono potępione i ofiary zostały otoczone szczególną opieką. Okazuje się, że statystycznie problem wykorzystywania małoletnich dotyczy bardziej czynów przestępczych wewnątrz rodzin (przez ojców, ojczymów lub przyjaciół matek) czy innych środowisk szkolnych, niż czynów duchownych. We wszystkich tych przypadkach mówi się o marginaliach, wyjątkach, natomiast co do grupy duchownych problem się powiększa. Nie jest to sprawiedliwa ocena zjawiska. Niemniej odpowiedzialne podejście do problemu domaga się właściwego zdiagnozowania go i wykrycia jego przyczyn oraz zastosowania odpowiednich środków, włącznie z polityką rodzinną i społeczną ${ }^{56}$. Papież Franciszek, który jest kontynuatorem działań poprzedników jednoznacznie stwierdza, że przestępstwa i grzechy wykorzystywania seksualnego małoletnich nie mogą być dłużej trzymane w tajemnicy. Zobowiązał się do gorliwej czujności Kościoła, aby chronić małoletnich i obiecał, że osoby odpowiedzialne zdadzą sprawę ze swoich czynów ${ }^{57}$.

Dokumenty kościelne, które wyżej były analizowane, pokazują szczególną troskę papieży i kongregacji o ochronę małoletnich. Dla

\footnotetext{
${ }^{56}$ Por. A. Domaszk, Reakcja Kościoła..., dz. cyt., s. 85.

${ }^{57}$ Por. Franciszek, PAPIEŻ, Dar odnowionej bliskości między rodziną a Kościołem, L'Osservatore Romano wyd. polskie, 36(2015), nr 10, s. 48.
} 
ułatwienia stosowania Norm (de gravioribus delictis) Kongregacja Nauki Wiary zwróciła się do poszczególnych Konferencji Episkopatów z Okólnikiem ${ }^{58}$. Chodzi o to, aby każda z Konferencji opracowała własne „wytyczne”, jako jasne i skoordynowane procedury w przypadkach nadużyć seksualnych.

Konferencja Episkopatu Polski w czerwcu 2009 r. (jeszcze przed okólnikiem z Kongregacji Nauki Wiary) przyjęła szczegółowe wytyczne dotyczące postępowania kościelnego w przypadku oskarżeń duchownych o molestowanie osób poniżej 18 roku życia. Natomiast w dokumencie z 9 października 2013 r. biskupi polscy oświadczyli: „Z całą mocą podkreślamy - nie ma żadnej tolerancji dla pedofilii. Takie stanowisko zajmuje cały Kościół w Polsce - tak duchowni, jak i świeccy katolicy". W 2014 r. Konferencja Episkopatu Polski przyjęła „Wytyczne dotyczące wstępnego dochodzenia kanonicznego w przypadku oskarżeń duchownych o czyny przeciwko szóstemu przykazaniu Dekalogu z osobą niepełnoletnią poniżej osiemnastego roku życia”. Zostały one zatwierdzone przez Stolicę Apostolską w 2015 roku. Wytyczne Episkopatu Polski są bardziej restrykcyjne niż obowiązujące prawo polskie. O tym, że Kościół nie milczy w kwestii wykorzystywania nieletnich świadczy też fakt, iż 3 marca $2017 \mathrm{w}$ polskich diecezjach był dzień modlitwy i pokuty w intencji ofiar pedofilii. Ponadto w 2014 r. w Krakowie miała miejsce liturgia pokutna za grzech pedofilii. W 2013 r. Konferencji Episkopatu Polski powołała koordynatora ds. ochrony dzieci i młodzieży, który jednocześnie kieruje Centrum Ochrony Dziecka. To Centrum, będąc instytucją kościelną, szkoli wielu duchownych odpowiedzialnych w diecezjach

\footnotetext{
${ }^{58}$ Por. Okólnik do Konferencji Episkopatów w sprawie opracowania „wytycznych” dotyczących sposobów postępowania w przypadku nadużyć seksualnych popełnionych przez duchownych wobec osób niepełnoletnich (dalej Okólnik Kongregacji 2011), 03.05.2011, http://www.vatican.va/roman_curia/congregations/cfaith/ documents/rc_con_cfaith_doc_20110503_abuso-minori_pl.html (data dostępu: 16.01.2017).
} 
i wspólnotach zakonnych za kwestię zapobiegania przestępstwom seksualnym $\mathrm{z}$ nieletnimi ${ }^{59}$.

Także instytuty zakonne włączyły się w troskę Kościoła o ochronę nieletnich stanowiąc odpowiednie przepisy. Dla przykładu tak uczynili Salezjanie ${ }^{60}$ i Michaelici $^{61}$. Jak widać cały Kościół katolicki, jak żadna inna społeczność, podjął zdecydowane działania, aby osądzić nadużycia seksualne duchownych i ochronić dzieci i młodzież.

\section{Zakończenie}

Polski Kodeks karny w art. 197-205 zajmuje się przestępstwami przeciwko wolności seksualnej i obyczajowości, w tym przemocą wobec nieletnich, jak wyżej to zostało przedstawione. Przestępstwa te, w dużej mierze pokrywają się z tym, co w materii wykroczeń przeciwko szóstemu przykazaniu Dekalogu zawierają przepisy kościelne. Może się zdarzyć, że wierny/duchowny dopuszczający się grzechu przeciwko szóstemu przykazaniu Dekalogu będzie mógł zostać pociągnięty do odpowiedzialności zarówno przez kompetentną władzę kościelną, jak i państwową. Wcześniejsza interwencja władzy państwowej nie zwalnia jednak władzy kościelnej z konieczności interwencji (por. kan. 1344 KPK). Należy podkreślić, że między polskim Kodeksem karnym a przepisami kanonicznymi istnieją różnice co do racji i kryteriów karania oraz samego karania. Kary państwowe dotyczą zakresu doczesnego, natomiast kościelne zakresu duchowego (zarówno poprawcze, jak i ekspiacyjne). Możliwe są zatem sytuacje domagające się dodatkowego ukarania na płaszczyźnie prawa karnego

59 Por. P. Rytel-Andrianik, Kościół nie milczy ws. pedofilii http://opoka.news/ aktualnosci/4219\#sthash.rXP3Pcal.dpuf (data dostępu 8.05.2017).

${ }^{60}$ Por. P. Chavez Villanueva, La vocazione a restare sempre uniti a Gesù per avere vita, Atti del Consiglio Generale 408(2010), s. 3-24; F. CEREDA, Formazione all'affettività e alla castità, Atti del Consiglio Generale 408(2010), s. 25-34; także A. Domaszk, Towarzystwo Św. Franciszka Salezego wobec zagrożenia nadużyciami seksualnymi względem nieletnich, Seminare t. 32(2012), s. 49-56.

${ }^{61}$ Por. Normy i zasady ochrony dzieci i młodzieży w praktyce wychowawczej i duszpasterskiej Zgromadzenia Świętego Michała Anioła, Marki 2016, s. 2-93. 
kanonicznego, pomimo zastosowanej już sankcji karnej na płaszczyźnie prawa państwowego ${ }^{62}$.

Współpraca państwa i społeczności kościelnej na rzecz ochrony nieletnich jest bardzo wskazana, ale też czasami unormowania moga budzić wątpliwości. Np. z dniem 13 lipca 2017 r. wejdzie w życie ustawa z dnia 23 marca 2017 r. o zmianie ustawy - Kodeks karny, ustawy o postępowaniu w sprawach nieletnich oraz ustawy - Kodeks postępowania karnego. Zasadniczą zmianą interesującą bezpośrednio każdego obywatela RP jest to, że od 13. lipca każdy, kto wejdzie w posiadanie wiarygodnej informacji o popełnieniu poważnego przestępstwa lub też o usiłowaniu popełnienia go na szkodę dzieci poniżej 15-tego roku życia, a także osób psychicznie lub fizycznie nieporadnych, jest zobowiązany zawiadomić niezwłocznie prokuraturę lub policję. Brak zawiadomienia, zgodnie ze znowelizowanym art. $240 \$ 1 \mathrm{kk}$ zagrożony jest karą pozbawienia wolności do lat 3. Do tej pory obowiązek zawiadomienia o podejrzeniu popełnienia takich przestępstw dla ogółu obywateli był obowiązkiem społecznym - bez sankcji karnej. Od 13. lipca 2017 roku jest to obowiązek prawny pod sankcją.

Z całości opracowania wynika, że osoby duchowne są potraktowane surowiej niż osoby świeckie w systemie prawa kanonicznego, gdy chodzi o przestępstwa natury seksualnej, w tym przestępstwa molestowania małoletnich i użytkowania pornografii dziecięcej. Jest to uzasadnione różnymi względami. Istotny jest również argument teologiczny. Nie można bowiem zapominać, iż duchowny w przypadku prezbiteratu i biskupstwa działa in Persona Christi Capitis w sprawowaniu kultu Bożego i dlatego przestępstwa seksualne jawią się jako niezwykle rażące sprzeniewierzenie się własnemu powołaniu prowadzenia ludzi ku Bogu. Szczególny ciężar przestępstwa molestowania seksualnego oraz pornografii dziecięcej wynika nie tylko z faktu naruszenia szóstego przykazania Dekalogu, ale przede wszystkim z gorszącego zamachu na integralność fizyczną, psychiczną i moralną małoletnich i osób z nimi zrównanych, które będą nosić jego piętno przez całe życie.

${ }^{62}$ Por. D. Borek, Sextum Decalogi ..., dz. cyt., s. 124. 


\section{The sexual violence against minors and their legal-ethical and canonical protection}

In the common good of the state and the Church there is care about the protection of children and young people. The task of these communities is initially to recognize and respect the rights of minors and the care to ensure the safe development environment, free of exploitation, violence and manipulation. The state and ecclesial communities are committed to the physical, spiritual and emotional growth of children and youth people and to the exclusion of the situation of any physical or mental violation of minors integrity. All abuses in this regard are widely condemned by both communities, and they cause righteous indignation. In the state and church legal system, acts related to violence against children and adolescents are considered serious crimes. Disturbing phenomena related to sexual harassment or child pornography have resulted in legislation that severely penalizes these crimes. The article will present crimes of sexual violence against minors in the legal-criminal, ethical and canonical systems. This comparative approach will be going to show the offenses in both systems, victims of crime and their perpetrators, the criminal sanctions and the real concern for the state and the Church for the protection of minors.

SŁOWA KLUCZOWE: dziecko; małoletni; przestępstwo; pedofilia; molestowanie seksualne; pornografia dziecięca; delicta reservata; Kongregacja Nauki Wiary

KEY WORDS: child; minor; crime; pedophilia; sexual harassment; child pornography; delicta reservata; Congregation for the Doctrine of the Faith

\section{Nota o Autorach:}

Ks. PROF. DR HAB. HeNRYK STAWNiAK SDB - prof. zw. dr hab. nauk prawnych w zakresie prawa kanonicznego, kierownik Katedry Kanonicznego Prawa Małżeńskiego i Rodzinnego, dziekan Wydziału Prawa Kanonicznego UKSW.

DR hab. Grażyna JARZĄBEK-Bielecka - dr hab. nauk o zdrowiu, kierownik Pracowni Ginekologii Wieku Rozwojowego i Seksuologii Kliniki Ginekologii Katedry Perinatologii i Ginekologii Uniwersytetu Medycznego im. Karola Marcinkowskiego w Poznaniu.

AnNa BieleckA-Gąszcz - sędzia Sądu Rejonowego w Łodzi. 